\title{
UNIVERSITIES PROMOTIONAL ACTIONS AS A WAY TO LEVEL THE EFFECTS OF DEMOGRAPHIC DECLINE
}

\section{IZABELA OSTROWSKA}

University of Szczecin, POLAND

e-mail: izabela.ostrowska@wzieu.pl

RECEIVED
ACCEPTED
JEL
CLASSIFICATION

KEYWORDS

ABSTRACT
2 May 2018

26 September 2018

M37, I23, J11

marketing, universities promotion, demographic decline

Since 2006, universities have been affected by the demographic decline, which causes that the number of students is decreasing in Poland. A smaller number of potential candidates for studies means that universities must actively promote themselves to encourage young people to choose their services. The article has a research character based on the analysis of available statistical data, the literature of the subject and the results of the survey. The aim of the study and the presented article is to identify places where young people undertaking full-time studies (as it is the dominant form of education at public universities) searched for information about studying opportunities and getting to know their opinions on places where the university should promote itself.

\section{Introduction}

In recent years, universities have begun to "feel" the effects of the demographic decline, which decreased the number of students in Poland. Forecasts show that the peak of this decline will take place in 2023. A smaller number of potential candidates for studies means that universities have to compete with each other and effectively encourage young people to choose a particular faculty at a given institution rather than at another university in the area. 
Otherwise, the group of students will be reduced every year and the university will be forced to reduce the academic staff. With time, it may turn out that the some of the buildings will become unnecessary and the university, instead of developing, will slowly sell out or rent space to other entities. This is not an optimistic vision, especially for faculties with a long-standing tradition and a significant scientific position. It is forecasted that only a hundred, out of a few hundred, of private universities will survive the decline. Currently, there are about 130 state-owned universities in Poland, however, they also suffer from the effects of demographic decline. Many, also renowned universities, recruit students for full-time studies by the end of September, because they are not able to obtain a sufficient number of candidates (https://www.forbes.pl/kariera/do-2023-roku-zostanie-w-polsce-100-uczelni-prywatnych/9917kvm).

\section{Method}

The article is based on the analysis of available statistical data, the literature of the subject and the results of the survey. The aim of the study and the presented article is to identify places where young people undertaking full-time studies (as it is the dominant form of education at public universities) sought information about studying opportunities and getting to know their opinions on places where the university should be promoted. The survey was conducted in January 2018 on a sample of 149 respondents in one of the economic faculties in the West Pomeranian Voivodeship (the sample was random, the selection was layered, $30 \%$ of students in 1st and 2nd degree studies at this faculty were analyzed). The analysis carried out due to the purpose of the article has been limited to the answers given by students who study full-time. The study is not representative, but it can be treated as a pilot and the basis for further research. However, the results obtained on such a small sample can be valuable due to their timeliness. It is intended to repeat the analysis annually to identify changes in the behaviors and preferences of young people."

\section{Students in Poland over the last decade}

Since 2006, the number of students in Poland has been systematically decreasing - Figure 1 shows the number of students per 10 thousand. residents. In the academic year 2016/2017, 1,348.8 students were educated in 390 higher education institutions. In comparison, in 2005/2006 it was 1,953.8 that is over 605 thousand. more people. Within 11 years, the number of students has decreased by $31 \%$. Schlarization rates are the measures of prevalence of education. Gross scholarization rate ${ }^{1}$ in higher education grew from $12.9 \%$ in the academic year $1990 / 1991$ to $53.8 \%$ in the academic year $2010 / 2011$, and then it fell, reaching $47.6 \%$ in the academic year 2015/2016. On the other hand, net scholarization rate ${ }^{2}$ grew - from $9.8 \%$ in $1990 / 1991$ to $40.8 \%$ in $2010 / 2011$, while in the academic year 2016/2017 it dropped to $36.8 \%$ (GUS, 2017, pp. 25-26). On this basis, it can be concluded that the peak of interest in higher studies in Poland has already passed. The percentage of people deciding to take up higher education after secondary school is lower, and the number of people aged 18-24 decreases, that is from the most important segment for the university (31.0\% drop compared to 2005$)$.

${ }^{1}$ Gross scholarization rate it is the ratio of the number of all learners at a given level to the total population of persons in the age nominally assigned to this level of education (for higher education 19-24, as of December 31) expressed as a percentage.

${ }^{2}$ Net scholarization rate on the other hand, shows the percentage of learners at the nominal age of education at a given level in the entire population of persons in the age nominally assigned to this level of education. 


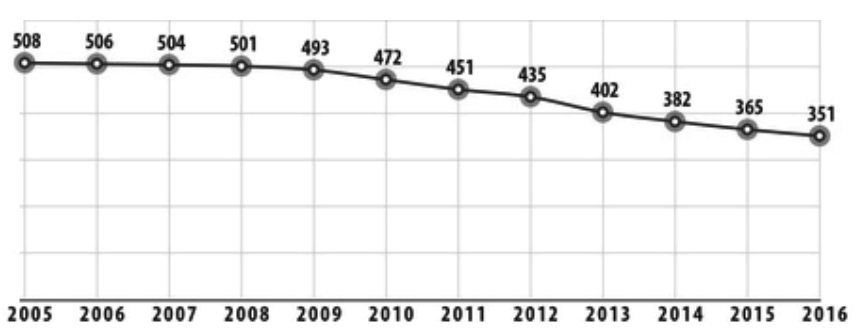

Figure 1. Number of students per 10,000 residents in Poland

Source: GUS (2017) data, as of 31.11.2016.

It is worth noting that public and private universities are competing on the higher education services market. Non-public schools have a significantly smaller share in the market of educational services, as shown in Figure 2.

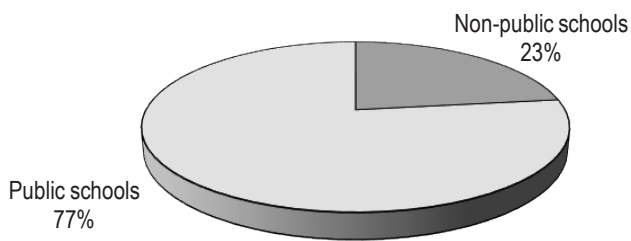

Figure 2. Share of public and non-public schools in the market of educational services

Source: GUS (2017) data (as of 31.11.2016).

In 2016/2017, there were 390 higher education institutions in Poland (including schools of the Ministry of National Defense and Internal Affairs and Administration). 132 of them were public universities in which $1,034.2$ thousand students were educated. ( $76.7 \%$ of all students, $76.5 \%$ in the previous year). In this period, there were 258 non-public universities educating 314.7 thousand students ( $23.3 \%$ of all students). In comparison to the previous year, the number of non-public higher education institutions dropped, and the number of youth studying there decreased by $4.7 \%$ (GUS, 2017, p. 28).

In recent years, an increasing share of students studying at public higher education institutions has been observed, in which full-time studies were the dominant form of education $-78.7 \%$ (78.0\% in 2015/2016). The opposite situation occurs in non-public higher education institutions in which part-time studies prevail. This form of education was used by $73.9 \%$ of students of these universities (75.7\% in 2015/2016) (GUS, 2017, p. 29).

For a student choosing to study in the daily system, the main difference is that in public institutions they do not have to pay for the services. In the case of full-time studies, public universities have a significant advantage over non-public institutions. As a result of the demographic decline on the market, practically every person planning to study on a daily basis will be able to easily get to the public university. In the context of the competition for students, full-time studies at non-public universities, which are paid, are predicted in the next 10-year period to almost completely disappear (https://www.forbes.pl/kariera/do-2023-roku-zostanie-w-polsce-100-uczelniprywatnych $/ 9917 \mathrm{kvm})$. Public universities compete for full-time students with non-public institutions, but due to the 
decreasing number of people undertaking studies, also the competition between public universities is becoming stronger.

\section{Promotion of educational services}

The thesis that the student will not choose a university they do not know is out of the question. The basic question is how to reach potential candidates for studies and how to construct a message to convince them to choose a given field of study and a given university. To this end, universities can take advantage of the achievements of marketing and profit from a variety of tools used by companies to communicate with customers. Marketing communication can be understood as the transmission of information between various market players that concern a company, product brand or other aspects of marketing activities undertaken (Bajdak, 2013, p. 44). Marketing communication tools that allow to influence consumer behavior include: personal sales, advertising, public relations, informal communication, sales promotions, sponsorship (Wiktor, 2013, pp. 7-8). These tools differ in terms of the specificity of impact and applications, but all of them can be used by universities to communicate with potential students. In the article, due to the limited content, the analysis will cover tools included in the advertisement and selected public relations activities.

\section{Constructing promotional messages}

As rightly observed by Łęgowski, the phases of consumer behavior on the market are noticeable. Common elements can be found in many different perspectives of the consumer's behavior process: identification (awareness) of the need, seeking information, evaluation of possibilities (alternatives), purchase decision, after-sales procedure (consumption of a certain value) (Łęgowski, 2017, p. 95). The process of selecting a university where a young person intends to study is very similar. The task of communication with a potential student is to provide information that will enable assessment of the available selection options and making a decision about willingness to study in a given field of study and at a specific university.

Effective marketing activities require time and proper recognition of the needs of consumers on the market, because only in this way can the recipient be convinced for a specific action. In the survey, students were asked what should be emphasized in promotional messages. The question about this aspect was of the open type, thanks to which every subject could freely answer the questions. The answers have been grouped into six main areas (Figure 3), the order of which reflects their validity, i.e. the frequency of a given answer.

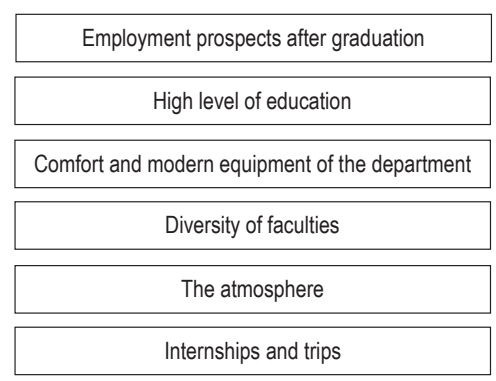

Figure 3. The most important factors when choosing a faculty in the opinion of the youth

Source: own elaboration based on the results of the survey. 
The "employment prospects after graduation" were most often emphasized by the students, that is, obtaining a good education enabling to take a well-paid job. Second was the "high level of education". For the respondents, it is important that the studies have value not only "on paper", but that the graduate should have real knowledge of the subject. For students it is also important in what conditions they will study, or "comfort and modern equipment of the department". This factor can be included in the material certificate in services on the basis of which potential consumers can form an opinion on the quality of services provided. Students are looking for study opportunities at the faculties where "diverse faculties" are offered. This is also important in the case of economic universities, where, in addition to economics, management, finance or accounting, nowadays such faculties as: logistics, tourism, real estate management, entrepreneurship and investments, economic analytics, economic consulting or human capital management are launched. The frequently appearing answers concerned also the "atmosphere of studying" which also included a friendly approach of lecturers to students. For modern young people, studying is also a period of gaining professional experience through internships, as well as trips to other universities. It is interesting that only a few people emphasized that they choose their studies in terms of opportunities to develop their own interests. Obtained answers show a pragmatic approach to the choice of studies, perhaps because the answers were given by students of economic studies. For those who create promotional information, the answers can be an indication of what aspects should be emphasized in order to convince young people to study at the faculty.

The second area studied was the search for information about the possibilities of studying by young people. The answers obtained are shown in Figure 4.

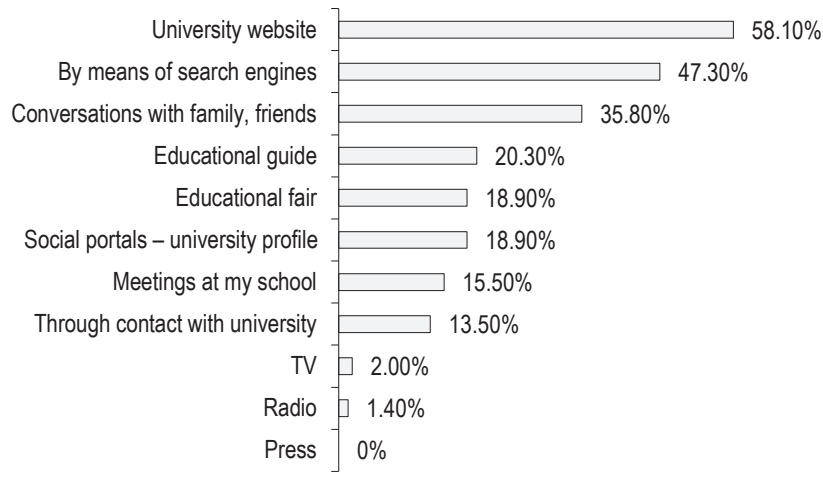

Figure 4. Places to search for information about the possibility of studying

Source: own elaboration based on the results of the survey $n=149$.

Internet is the most important place to search for information, which is shown by the results obtained. However, the search for information about study opportunities also has its specificity, resulting from the great importance of information reliability. For this reason, young people mention in the first place websites of individual universities (58.1\% of responses), which are a reliable and comprehensive source of information about the available fields of study, specialties and recruitment conditions. Search engines take the second place ( $47.3 \%$ of respondents). Thanks to them potential students using keywords can search for specific faculties or specialties and universities, which offer them. Direct talks about college, carried out with friends and family are important (almost $36 \%$ 
of responses), but they complement the knowledge obtained independently on the Internet. Information presented in educational guides (20.3\% of answers) and at educational fair (almost $19 \%$ of respondents) is of less importance but it is worth noting that for $1 / 5$ of the respondents they were an important source of information about the university's offer. In the next place the respondents mentioned social networking sites in which they viewed profiles of individual universities (18.9\% of responses). Interactions during meetings organized in secondary schools are also important for young people, but definitely to a smaller degree (15.5\% of responses). Perhaps this is due to the fact that schools cannot organize many of such meetings, because they disturb the rhythm of work at school, especially in three-year high schools, where there is not much time to prepare for the final exams. These meetings certainly do not show the entire spectrum of study opportunities, which is why young people can treat them as a starting point for independent exploration of a given subject. Direct interaction with the university, in order to obtain information on the offered courses, was indicated only by $13.5 \%$ of respondents. This means that the information posted on the Internet or in educational catalogs was so comprehensive that a small part of the respondents felt the need for talk or email communication to deepen the subject. Other mass media - TV, radio and press were not listed as an important source of knowledge about study opportunities (less than $2 \%$ of indications).

The conclusions from the analysis of the answers given by the young are unequivocal. Universities must first of all inform about their offer on the Internet. The primary place is the university site, where potential candidates seek information. This site should be attractive and modern, but above all it should convince the young person that it is worth studying in a given field and that a particular university is the best choice of place of study. At this point, it is worth recalling the results of the answers to the previous question, i.e. what should be displayed on the website. The communication should emphasize the possibilities of employment after a given faculty, high level of education, show the comfort and modernity of the faculty, large selection of specialties, friendly atmosphere and prospects for valuable apprenticeships or trips within student exchange programs.

On the other hand, universities have to attract potential students to their website and it is necessary to position them in search engines so that candidates can find the offer of a given university in the search results, for example, "accounting", "tourism" or "logistics" in the first positions. Young people live in the world of social media, which is why universities should also be active in them. These media are governed by specific laws, and the flow of information about the university is multifaceted. On the one hand, the university can actively shape its image, create its own profile and place attractive information on them. On the other hand, it will depend on the users' activity on how much the profile will be visible - liking pages and making them available to friends causes that "friends" of the students or sympathizers learn about the university. Each participant of a social media can be identified by means of a place of residence, but also by a place of study or work. Therefore, for the university to be visible in social media, it should care for relations with current students, employees, as well as the graduates. All these groups, if they feel connected to the university and identify with it, will be happy to display its name on their own profile, and actively participate in events organized on the university profile, becoming its ambassadors. Potential students visiting the profile of the university or faculty, can trace its timeline and see what events were taking place, how many people liked them and how they were commented. For this reason, the profile of the university/faculty should be managed throughout the year, not incidentally before the recruitment period. It is worth remembering that communication with friends and family is the third source of information about studying opportunities. That is why strong relationships built with the faculty community are the basis of promotional activities and cannot be based only on virtual actions. It's worth remembering that communication with friends and family is the third source of information about studying 
opportunities. Therefore, strong relationships built with the faculty community are the foundation of promotional activities and cannot be based only on virtual activities.

The survey also included a question about where the university should advertise - the answers obtained are shown in Figure 5. While the previous question referred to how young people acted in the past, this question refers to their ideas about the choice of communication channels with young people.

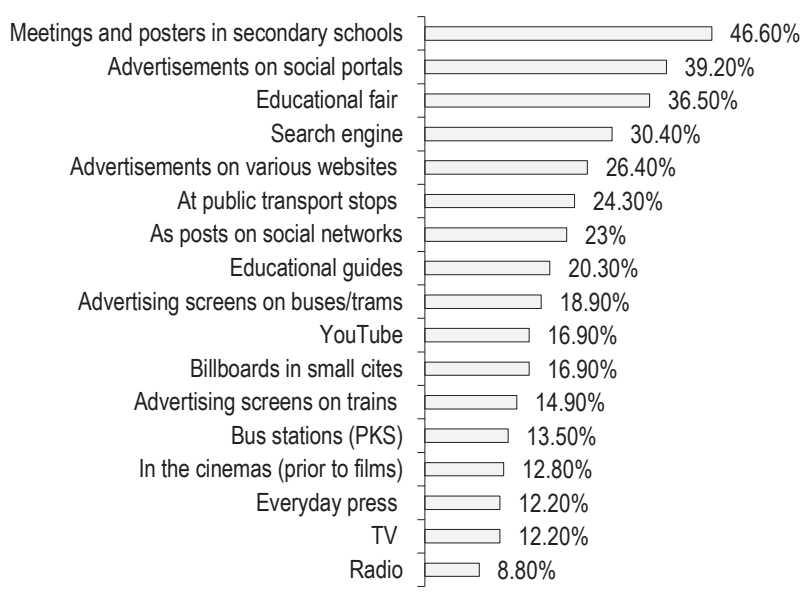

Figure 5. Preference for placement of promotional information about the study offer Source: own elaboration based on the results of the survey $n=149$.

The analysis of the answers obtained may be surprising, as the first place included activities carried out directly in secondary schools, i.e. meetings and information posters ( $46.6 \%$ of indications). This means that young people notice the need to reach potential candidates directly with information, in a very traditional way, through a conversation with a university representative or an information poster. There is a valuable indication in this observation that no mass-scale activities can replace a direct relationship with a university representative. Comparing this result with the answers to the previous question, it can be noted that perhaps young people rarely had the opportunity to participate in such meetings, because only $16 \%$ of them indicated that they were looking for information about the possibilities of studying during such meetings. Students also emphasize the value of attendance at educational fair (36.5\% of responses), despite the fact that they did not use this source of information themselves (less than 19\% of responses).

The remaining answers no longer differ significantly - the university should advertise on social media by displaying advertisements ( $39 \%$ of indications), in search engines ( $30.4 \%$ of indications) and through advertisements displayed on various websites on the Internet ( $26 \%$ of responses). It is worth noting that current students notice the importance of advertising in public space - at public transport stops (24.3\% of responses), on public transport screens (almost $19 \%$ of indications), on billboards in smaller towns (16.9\% of responses), on advertising screens on trains (14.9\% of indications), at PKS bus stations ( $13.5 \%$ of indications) or in cinemas ( $12.8 \%$ of responses). 
The overview of opinions on mass media not used by the respondents themselves, but considered as a good place to advertise is also interesting. For daily press $(12.2 \%$ of responses as ad space, but $0 \%$ of indications as source of information about the offer), for television ( $12.2 \%$ vs. $2 \%)$, and radio ( $8.8 \%$ vs. $1.4 \%$ of responses). One can try to explain by the fact that young people perceive advertising not as a reliable source of information, but rather as a way to build brand awareness and create a positive image. Analyzing the answers obtained, it can be noticed that the university must invest in direct relations with potential students and advertise primarily on the Internet. At the same time, the university should be visible in the surroundings to build an image among the local community, from which only a small percentage will be personally interested in the university advertisement. This promotion strategy is justified by the fact that young people eagerly choose known and popular universities ${ }^{3}$, and parents who have an influence on their choices can be reach easier via traditional communication channels.

\section{Conclusions}

In the face of many changes and the speed of their occurrence on the market, especially those caused by demographic trends, universities must take active promotional activities in order to reach potential students with information and persuade them to their offer. The concept of promotional activities addressed to young people must be adapted to the specific needs of this market segment and the communication channels used. In this area, there are also quick changes that universities should respond to. The article discusses the results of the survey conducted in 2018, which can be treated as an indication of how to distribute the budget for individual communication channels and how to construct a message to reach potential students and convince them to choose a faculty and university. This is necessary as demographic trends clearly indicate that the drop in the number of students is inevitable by 2023, which may result in closing unpopular departments and connecting universities to improve their profitability.

\section{References}

Bajdak, A. (2013). Komunikacja marketingowa przedsiębiorstw a budowanie relacji z podmiotami otoczenia na rynkach zagranicznych. Studia Ekonomiczne. Zeszyty Naukowe Uniwersytetu Ekonomicznego w Katowicach, 140.

GUS (2017). Szkoły wyższe i ich finanse w 2016 roku. Warszawa.

https://www.forbes.pl/kariera/do-2023-roku-zostanie-w-polsce-100-uczelni-prywatnych/9917kvm (26.02.2018).

Łęgowski, S. (2017). Budowanie relacji z klientem jako determinanta lojalności i satysfakcji konsumenta na rynku telefonii komórkowej. Studia Ekonomiczne. Zeszyty Naukowe Uniwersytetu Ekonomicznego w Katowicach, 328.

Wiktor, J.W. (2013). Komunikacja marketingowa. Modele, struktury, formy przekazu. Warszawa: Polskie Wydawnictwo Ekonomiczne.

Cite this article aS: Ostrowska, I. (2018). Universities promotional actions as a way to level the effects of demographic decline. European Journal of Service Management, 3 (27/1), 189-196. DOI: 10.18276/ejsm.2018.27/1-23.

${ }^{3}$ In another question in the survey, as a reason for choosing a specific department, $21 \%$ of respondents mentioned a good image, and $5.4 \%$ of respondents indicated the opinion of parents. 